\title{
Bureaucratic Reform Analysis through Performance of Hospital Employees
}

\author{
Suardi ${ }^{1}$, Ermaya Suradinata ${ }^{2}$, Kusworo ${ }^{3}$, Ali Hanafiah Muhi ${ }^{4}$ \\ 1,2,3,4 Institut Pemerintahan Dalam Negeri (IPDN), Indonesia \\ Email: suardi.ipdn@gmail.com
}

\begin{abstract}
This study examines the influence of bureaucratic reformation toward employee performance of the area general hospital Dr. R. Soedjono Selong in East Lombok Regency NTB Province with the number of respondents 270 employees, with stratified random sampling method. This research uses mixed method which combine quantitative and qualitative approach. Mixed method is used because in this research produce two kinds of data, taht is quantitative data and qualitative data. Mixed method is a research approach that combines or associates qualitatif forms, which is basically a combination of both qualitative and quantitative approach, so using a mixed can produce a comprehensive fact in researching the research problem, because in research the researcher has the freedom to use all data collection tool in accordance with the type of data required. Based the results of the study show that bureaucratic reformation variables significantly influence the employee performance ( $p$ value $=0,000$ atau $<0,05$ ) with a large value of the middle influence of 0,422 , which preves that the higher the level of bureaucratic reformation the better the employee performance. The work culture variables has a sigificant effect toword the employee performance ( $p$ value 0,001 atau $<0,05$ ) with a large value of the low influence of 0,211 , which preves that the higher the level of bureaucratic reformation the better the employee performance. The new findings generated from this research are the ARITMATIC model (Ability, Responsibility, Innovation, Team Work, Motivation, Agility, Technology, Information and Culture) abtained from the results of ASOCA analysis.
\end{abstract}

Keywords: bureaucratic reformation, government, employee performance.

\section{A. INTRODUCTION}

The inevitability of development and renewal in the life of the Indonesian people is not only driven by the current wave of reform, but it is also realized that entering the globalization era of the twenty-first century with all its reality and challenges there must be a variety of fundamental changes, both structurally and culturally. Development becomes a chain and an integral part of comprehensive reforms that are taking place today (Suradinata, 2002: 49). This principle requires maximum bureaucratic performance in carrying out public services, as well as a dynamic and constructive check and balance mechanism of the legislative body. Quality bureaucracy will be able to balance these development partners in encouraging the improvement and innovation innovations needed by the region.

The overly long and convoluted range of bureaucracy from bureaucrats will hamper the performance of the bureaucracy. Bureaucracy is an organizational structure in the government sector that has a very broad scope of tasks and requires large organizations with large numbers of human resources. In reality, bureaucracy is to carry out 
governance, development and services to the community. But in reality government bureaucracy often causes problems.

Indonesia currently has guidelines in implementing Bureaucratic Reform, namely Perpres Number 81 of 2010 concerning the Grand Design of Bureaucratic Reform 2010-2025 and Permenpan Number 20 of 2010 concerning Bureaucratic Reform Road Map 2010-2014. The objectives of the Bureaucracy Reform are stated to: Form a professional bureaucracy with characteristics: adaptive, integrity, high-performance, free and clean from KKN, able to serve the public, neutral, dedicated, and uphold the basic values and ethics of the state apparatus and the existence of a guidance system career. From this policy, it was found that there are eight areas of change which are also called targets, namely 1) Organization; 2) Management; 3) Apparatus Resources; 4) Laws and Regulations; 5) Supervision; 6) Accountability; 7) Public Services and 8) Mind set and apparatus culture This research focuses on: Culture of the apparatus.

The Ministry of PAN-RB develops the basic values that underlie the quality of the resources of the state civil apparatus, namely 1) Integrity, prioritizing commendable, disciplined and dedicated behavior; 2) Professional, completing tasks well, thoroughly, according to competency (expertise); and 3) Accountable, accountable for both tasks, in terms of process and results. These values are the goals of bureaucratic reform and are expected to be able to overcome various issues of accountability. In the health sector, the Ministry of Health also implements bureaucratic reform at all work unit levels. One form of implementing bureaucratic reform is the Organizational Structuring and Strengthening Program and the Apparatus Management System Arrangement Program. The target to be achieved is that the Ministry of Health organization is built based on business processes so that it functions appropriately and ensures the integration of effectiveness and efficiency of work implementation as well as the presence of competent, professional and high-performing resources, so that it is expected to provide better services. To support this effort the Minister of Health of the Republic of Indonesia made the Minister of Health Regulation of the Republic of Indonesia No. 1144 / Menkes / Per / III / 2010 concerning Organization and Work Procedure of the Ministry of Health in order to encourage organizations to maximize performance (Menkes RI, 2010). No exception in all hospital services which are public service units.

Based on data from the Ministry of Health, it is stated that in 2012 the number of hospitals in Indonesia was 2,083 units, while in 2014 the number of hospitals was registered 2,520 units, which means that within 2 years it had increased by around $21 \%$ and in 2017 the number of hospitals had reached 2790 (RI Ministry of Health, 2017). This condition will cause competition among hospitals to always try to improve services so that they are of public interest. As stated by Griffin (2007) that productivity and quality are competitive tools of a company.

The increase in the number of hospitals is not directly proportional to the availability of human resources, facilities and infrastructure. Therefore it is often a source of 
problems when there is an imbalance in service to the community served as a result the level of patient satisfaction decreases. For the middle to upper economic community, they will look for hospitals with a higher type and even they often seek hospitals overseas due to dissatisfaction with hospital services in Indonesia, for example to Singapore, Malaysia and other countries.

A pile of hospital-related problems in Indonesia seems to be endless. Starting from the case of death, neglect of patients, lack of human resources, and environmental pollution issues. Surely this is not a proud story. Moreover, if stakeholders do not take lessons and actions from a series of events as material for evaluation of the applicable system. Recently, what happened to a baby named Debora at Mitra Keluarga Hospital is being discussed hotly. This incident opened the eyes of the public that the health service was not friendly to the community. In fact, a hospital is a facility that provides health services to improve the level of public health.

During carrying out services to the community Dr. Hospital R. Soedjono Selong still has many shortcomings so that he has not been able to satisfy the patient and his family as expected and often even gets protests from the patient's family, community and NGOs. The still weak work culture implications that can be seen from the presence of unfriendly and less communicative medical staff are problems related to behavior and habits, as reported in a mass media.

Based on the phenomena and previous research above, this research was carried out in Indonesia, specifically highlighting Bureaucratic Reform and Work Culture in Regional General Hospitals, in this case as one of the agencies that have the function of providing health services, of course, must comply with established standards.

\section{B. LITERATURE REVIEW}

\section{The Concept of Governmental Science}

The science of governance can be defined as the study of how to meet and protect each person's needs and guidance in public and civil services. In government relations, (so it can be accepted) when needed by those concerned (Ndraha, 2011: 16). Government in a broad sense has the authority to maintain peace and security of the country into and out of the country. Therefore, firstly, it must have military power or ability to control the army, secondly, it must have legislative power or in the sense of making laws, thirdly, it must have financial strength or strength to suffice public finances in order to finance the costs of the state's existence. in implementing regulations, it is in the context of implementing state interests (Strong, 1960:6).

Apter (1965: 84) defines Government is the most generalized membership unit processing procedure (a) defined responsibilities for maintenance of the system of which it is a part and (b) a practical monopoly of coercive power. The government is the most common member who (a) has certain responsibilities to maintain a system that includes it, it is part and (b) a practical monopoly on coercive power. 
According to Wilson (1903:572), Government in last analysis, is organized force, not necessarily or invariably organized armed force, but two of a few men, of many men, or of a community prepared by the organization to realize its own purposes with references to the common affairs or the community. The government in the end of the description is an organization of strength, not always related to the armed forces organization, but two or groups of people from many groups of people prepared by an organization to realize their common goals and objectives, with things that give to the people general public affairs.

\section{Public Administration Theory}

Looks at public administration as an activity of the government providing public services with the primary objective of adjusting the policies issued by the government to complaints and public expectations. Because of its orientation to the public or the people, the state tries in such a way as to serve its people. In the past, people served the state/government, so now the government / state is a servant to the people.

Denhard and Denhard divided the state administration paradigm into 3 paradigms, namely Old Public Administration (OPA), New Public Management (NPM) and New Public Service (NPS). The most recent paradigm in state administration according to Denhard and Denhard is NPS. The development of Public Administration is a very important and fundamental thing, because it must be able to harmonize and follow the dynamics of a rapidly changing society. Public Administration in the sense of governance has the function of setting Public Policies that are in harmony and balance with the progress of the times.

\section{Public Policy Theory}

Public Policy, according to Riant Nugroho (2008: 68), is a decision of the State's authority which aims to regulate shared life. Where the objectives of public policy can be distinguished in terms of resources or risk, that is, between public policies aimed at distributing State resources and those aimed at absorbing state resources. Leo Agustino in his book Fundamentals of Public Policy (2008: 6) draws conclusions from several main characteristics and a definition of public policy. First, public policy is concerned with actions that have a specific purpose or goal rather than altered or random behavior. Second, public policy basically contains parts or patterns of activities carried out by government officials rather than separate decisions. Third, public policy is what the government actually does in regulating trade, controlling inflation. Fourth, public policy can be either positive or negative. Positively, the policy involves some clear government actions in dealing with a problem, negatively public policy can involve a government official's decision not to take an action or not do anything even though in that context government involvement is needed. Fifth, public policy is at least positively based on law and is a governing action. 


\section{Bureaucratic Reform}

Bureaucratic reform based on Max Weber's theory is a strategic effort in reorganizing the ongoing bureaucracy in accordance with the principles of span of control, division of labor, line and staff, rulle and regulation, and professional staaf (Setiyono, 2004: 125). Bureaucratic reform can be said to be reforming on being reformed, the struggle to uphold the law and the constitution; a change for better in morals, habits, methods; steps to reform the public sector (public sector reform) in an effort to realize good governance (good governance) and clean government (clean government) as a vehicle for realizing civil society.

Bureaucracy has the origin of the word Bureau, used in the early 18th century in Western Europe not only to refer to the desk, but rather to the office, such as the workplace where employees work. The original meaning of bureaucracy comes from the French language means upholstery of the table. The word bureaucracy itself was later used immediately after the French Revolution of 1789, and then spread to other countries. The word affix-kratia comes from the Greek or kratos which means power or leadership. Bureaucracy basically means office power or leadership from the staff.

Bureaucracy, according to Poerwadarminta, basically looks at it from the point of view of the government or the public servants who carry out the tasks of the government are called bureaucrats. The thought of a Max Webber is most widely used as a reference to bureaucracy. Uniquely Max Webber himself never definitively mentioned the meaning of bureaucracy (Albrow: 1989), Webber simply mentioned this concept and then analyzed the characteristics of what should be attached to bureaucracy.

Weber described the ideal type of bureaucracy in a positive tone, making it more of a national and efficient form of organization than alternatives that had previously existed, characterized as charismatic and traditional dominance. According to its terminology, bureaucracy is part of legal domination. However, he also stressed that bureaucracy is inefficient when decisions must be adopted in individual cases. According to Weber, the attributes of a modern bureaucracy include his personality, concentration of administrative meanings, effective enhancement of social and economic differences and implementation of a practical authority system that cannot be destroyed. Weber-style bureaucracy is also known as "Weberian bureaucracy".

\section{Factors Affecting Employee Performance}

Employees' performance varies from employee to employee. Broadly speaking according to Mar'at (2001: 91) performance is influenced by two things, namely individual factors and situation factors. The performance produced by these employees is different due to different individual factors, such as the existence of differences in abilities, physical, motivation, and other individual factors. Situation factors also affect the level of performance achieved by a person. Supporting situations include good business facilities, a quiet room, recognition of the opinions of other colleagues, leaders who un- 
derstand the needs of employees and are democratic. A supportive work system will certainly encourage the achievement of high performance rather than unsupportive working conditions, where there are authoritarian leaders, unsatisfactory services, pressure on roles, will certainly lead to low employee work performance. Meanwhile, in the opinion of Keith Davis in Mangkunegara (2012: 13), the factors that influence the achievement of performance are the ability factor (Ability) and motivation factor (motivation) which are formulated as follows: Human Performance = Ability $\mathrm{x}$ Motivation Motivation $=$ Attitude $x$ Situation Ability $=$ Knowledge $x$ Skill .

\section{Employee Performance}

In the conception of social agreement theory, J.J Rousseau in Haricahyono (1986: 55-56) said that: "the government is formed on the basis of mutual agreement among a group of people to better manage shared life". One form of better management of shared life is the fulfillment of shared needs which, due to their nature and problems, must or are more precisely implemented by the government. The administration of shared affairs or needs by the government is called public service. In a country that embraces democracy, the view that the government is the servant of the community is deeply rooted in the community. This is related to the view of people's sovereignty, namely, the government of the people, by the people, and for the people. In this connection, Osborne and Geabler (1995: 192) state that: "democratic governments are born to serve their citizens, and that is why the government's task is to find ways to please its citizens".

In relation to the organization, organizational performance is a picture of the performance of its employees. It was as stated by Prawirosentono (1999: 72) that "If employee performance is good then the possibility of company performance is also good", or vice versa according to (Gibson et.al, 1999: 13) "Individual performance is the basis of organizational performance". The good performance of these employees is inseparable from the existence of a conducive work environment, such as workplace conditions, work equipment, and other facilities, as well as the provision of incentive systems, employee selection and placement, task design and provision of education and training will have an impact on attitudes and behavior employees and can encourage employee motivation for achievement shown through performance.

On the other hand, Mitchell in Sedarmayanti, (1996: 51) suggests 5 (five) aspects to assess or measure the level of employee performance, namely: 1. Quality of Work, 2. Promptness; 3. Initiative; 4. Capability; 5. Communication. With reference to all the previous descriptions, in the context of this study the authors can point out that what is meant by employee performance is the level of achievement of work results / work performance or employee work productivity in carrying out obligations, basic tasks and functions that are the responsibility for achieving the best performance as a State Civil Apparatus so that the public, especially in hospital services get excellent service and the 
community feels satisfied.

\section{Framework of thinking}

Bureaucratic reform through hospital accreditation must start from the institutional arrangement and human resources of the apparatus. The next step is to make simple mechanisms, arrangements, systems and procedures that are not straightforward, enforce the accountability of the apparatus, increase and create comprehensive supervision, and improve the quality of public services towards quality and excellent public services, through 1) Institutional: streamlining the structure efficient and effective. 2) Human Resources Apparatus: professional, neutral, welfare, management, PNS productivity, transparent, clean and free of KKN 3) Governance: Management of the government apparatus is simplified, mechanisms, systems, procedures, work procedures 4) Accountability of Apparatus Performance: planning and budgeting, 5) Oversight: system / waskat, wasnal, and wasmas, coordination, integration 7) Public Services: transparency and accountability, not convoluted, informative, accommodating, consistent, fast, precise, efficient, transparent and accountable.

\section{Research Hypothesis}

Based on the conceptual framework of the study, the following research hypotheses can be formulated: Hypothesis 1: There is an influence of bureaucratic reform on employee performance at Dr. R. Soedjono Selong, East Lombok district. Hypothesis 2 There is no effect of bureaucratic reform on employee performance at RSUD Dr. R. Soedjono Selong, East Lombok district.

\section{RESEARCH METHODS}

This research uses a mixed research approach which combines quantitative and qualitative approaches. Mixed research methods are used because in this study produces two types of data, namely, quantitative and qualitative data. Creswall (2014) states that, "Mixed methods research is a research approach that combines or associates qualitative and quantitative forms."

As a social research related to measurement and evaluation, the mixed method is basically a combination of qualitative and quantitative approaches. Mixed method is a research method that combines quantitative and qualitative approaches in the stages of the research process and research methodology, so that by using mixed methods can produce comprehensive facts in researching research problems, because in his research researchers have the freedom to use all data collection tools in accordance with the type of data required. And in this research, concurrent mixed methods are used.

Furthermore, using quantitative explanatory methods translated in a variable operationalization that is focused on the characteristics or indicators so that it can be sufficient to be used as a design in the statistical testing model. Thus it can be explained 
the effect of bureaucratic reform and work culture on the performance of RSUD Dr. Raden Soedjono Selong, East Lombok district.

The research variable is an attribute or nature or value of people or objects that have variations between one another in the group (Sugiyono, 2002). Based on the framework described, the independent variable $(X 1)$ in this study is bureaucratic reform, and the independent variable (X2) is the work culture while the bound variable $(Y)$ is the performance of Dr. RSUD employees. Raden Soedjono Selong, East Lombok district.

\section{RESULTS AND DISCUSSION}

\section{Descriptive Analysis}

Respondent characteristic data in this study consisted of age, gender, length of work, education, type of profession and current employment status. The composition of respondents is also based on the age group ie the average respondent is aged between 36 to 40 years $(39.6 \%)$. This reflects that respondents as the implementation of public service programs in hospitals have a productive age with excellent stamina and enthusiasm, so that they can provide the best service, quickly and precisely according to the demands of bureaucratic reform. Based on the gender of respondents $54.1 \%$ more women) compared with male respondents (45.9\%). Gender greatly influences the effectiveness of carrying out tasks to improve organizational performance, including improving public quality. Female gender indicates that human resources are psychologically softer in providing services, always ready to serve the users of the service (customer).

\section{Test Validity and Reliability of Instruments}

An information is classified as scientific if it meets the validity (valid) and reliability (reliable) requirements. Therefore, in research, before further analysis is carried out, the stages of validity and data reliability testing are needed. The essence of validity is accuracy, and the essence of reliability is consistency / stability. An instrument / measuring instrument is said to be valid if it is able to measure what should be measured. While it is said to be reliable if repeated observations are made, the results are relatively the same or consistent.

To see the frequency distribution of bureaucratic reform variables (X1) in Dr. R. Soedjono Selong, an analysis has been carried out with the result that the bureaucratic reform variable $(\mathrm{X} 1)$ is explained by six dimensions and 24 indicators. There are at least nine indicators that support the success of the agency in managing bureaucratic reform, namely indicators of initiative (X18), motivation (X19), commitment (X16), courage (X17), discipline (X21), responsive (X23), synergy (X24) ), balance (X9) and alignment (X10). The nine indicators or aspects are included in the dimensions of leadership, work procedures, and relations.

According to several studies on the performance of bureaucratic reform on the 
aspect of leadership in Indonesia, the direction of conclusions is similar: most of the bureaucratic reform process has not been successful, a few have succeeded, and the rest have not worked at all. One thing that is interesting is that most regions led by reformist individuals are able to show good bureaucratic changes.

In addition to the leadership dimension, the work governance dimension also contributed greatly to the ongoing efforts of bureaucratic reform at Dr. Hospital. R. Soedjono Selong. Work procedures are the most efficient ways of carrying out work on a task by remembering aspects of objectives, facilities, labor, time, space and costs available (Sedarmayanti, 2009: 134). Meanwhile according to the Presidential Decree Number 47 of 2015 concerning the Ministry of Administrative Reform and Bureaucratic Reform, work procedures include: work relations, reporting systems, job descriptions, coordination systems, integration \& synchronization, and internal control systems. Work procedures are important as a work pattern that is a translation of goals, objectives, work programs, functions, and policies into the activities of carrying out tasks such as decision making, determining policy and conducting oversight in an agency. Therefore, organizations that want to achieve satisfactory goals and results must have work procedures that are made appropriately, can be standardized and controlled with work precisely.

Relationships are expected to improve the performance of bureaucratic reform. Although classified as good, there are still opportunities and hard work is needed to achieve better performance of bureaucratic reform. There are at least six indicators that should be of concern to Dr. Hospital R. Soedjono Selong to improve the performance of bureaucratic reform, namely indicators of discipline (X1.21), courage (X1.7), appreciation (X1.14), tupoksi well-built (X1.7), feasibility (X1.4) mutual control (X1.12) and the weakest is the responsiveness indicator $(\mathrm{X} 1.21)$.

\section{Employee Performance Improvement Model Dr. R. Soedjono Selong, East Lombok Regency}

The model is a simple representation of selected aspects of a problem condition that is arranged for a particular purpose (Dunn, 1994:33). Models are useful for explaining complex problems through simplifications in the form of schematics, mathematical models, physical models, symbolic models, and others. The model is also useful to facilitate the description of problems structurally, helping to predict the consequences arising from the presence or absence of changes in causal factors. There are two types of models, namely schematic models and symbolic models. Schematic models refer to models that use images, lines and points to point to elements and illustrations of their relationship with others. Whereas symbolic models refer to models that use words, equations or computer programs to present elements and illustrate their relationships. To explain the right strategy to be used in improving the performance of RSUD Dr. R. Soedjono Selong, compiled a symbolic model which the writer formulated as an "AR- 
ITMATIC" model consisting of Ability, Responsibility, Innovation, Team Work, Motivation, Agility, Technology, Information and Culture, with the following explanation:

1. Ability

Ability is the capacity of an individual to perform various tasks in a job (Robbins, 2008: 56). Every individual in an organization including the local government bureaucracy is required to always have the ability (knowledge, skills and attitudes) as the basis for improving organizational performance. The ability of each individual is one of the basic assets for an organization to achieve its goals. Ability is a basic component in ASOCA analysis.

2. Responsibility

Responsibility or responsibility is the obligation of someone as a rational creature and free not to dodge and provide an explanation of his actions retrospectively or prospectively. Based on that responsibility is interpreted as the readiness to provide answers to actions that have been taken in the past or in the future. For example, if a nurse deliberately installs contraceptives without the client's consent, it will have an impact on the client's future. Clients will not have children even though having children is the right of all humans. Nurses retrospectively must be able to take responsibility even though the nurse's actions are considered correct according to medical considerations.

\section{Innovation}

Innovation is a process and / or results of the development of the utilization of a product / resource that has already existed so that it has more meaningful value. Innovation is also interpreted as a renewal of various resources so that these resources have more benefits for humans. Sagat innovation process is influenced by advances in technology and science because both of these can make it easier to produce something new and different. Basically, the benefits of innovation are to perfect or improve the function of utilizing a product or resource so that humans get more benefits. This innovation process takes place continuously in human life because of the desire to do things that is easier and faster. Team Work According to Robbins, teamwork is a positive synergy through coordinated effort. The efforts made by team members produce higher performance than the individual input of each member. Team work is a combination of the behavior of several individuals, team work is a combination of knowladge, skills and attitude aimed at supporting team members and achieving team goals. One of the biggest advantages that will be received after doing teamwork is to get inspiration and new ideas from discussions with the team. In an effective team environment, staff members will feel confident in expressing their ideas. Responsibility towards superiors becomes joint responsibility. Working in teams can also get colleagues to solve problems through different perspectives according to their background and work experience. 


\section{Motivation}

Motivation is the reason for an action done by an individual. Someone said to have high motivation can be interpreted that the person has a very strong reason to achieve what he wants. A person's motivation can be generated and grow through himself-intrinsically and from the extrinsic environment (Elliot et al., 2000, Sue Howard, 1999). Intrinsic motivation means the desire of oneself to act without external stimulation. Intrinsic motivation will be more beneficial and provide a variety of learning. Extrinsic motivation is described as motivation that comes from outside the individual and cannot be controlled by the individual.

5. Agility

Intelligence comes from the word "smart" which means perfect development of the intellect, sharp mind, perfection in its growth, perfection of the mind, sharpness of mind and intelligence. Ability alone is not enough, must be with intelligence in managing thought, analyzing information to be used as decision material. the ability to hold back, control emotions, understand the emotions of others, high motivation, being creative, having empathy, being tolerant and so on are characteristics that are far more important than intelligence.

6. Technology

In the area of health, patient safety must be number one target. For this reason, the quality of service for patients is always a top priority in various health facilities such as hospitals, health clinics and health centers. Hospital technology to improve patient services is so important, one of which is information technology. The use of technology in hospital can save the place and scope of work of medical officers. Officers no longer record it on paper / books and save it in the form of documents off. With a computerized system, patient data can be safely stored on a computer.

7. Information

As a referral service center, all hospitals including Dr. R. Soedjono Selong needs data and information, to determine policy. The hospital is obliged to make a report. Hospital reporting that is good and right depends on hospital data, so we need an information system that regulates and oversees how to fill and process hospital data so that a Hospital Information System (SIRS) is needed.

\section{Culture}

The hospital as an organization is affected by cultural change. If the hospital is affected by a new culture, there is a possibility of conflict. As an illustration in a hospital there is a cultural conflict between groups who want efficiency-based changes with professional culture that actually wants the opposite. The emergence of a policy to improve efficiency in hospitals is part of the demands of the new culture of hospitals that are influenced by global culture. Meanwhile, there is a group of doctors who have a culture of thought that work efficiency in gov- 
ernment hospitals is not a measure for evaluating achievement and life achievement. This situation will cause cultural conflict.

\section{CONCLUSION}

Based on the results of the analysis and discussion in the previous chapter, some conclusions can be obtained as follows:

1. The variable bureaucratic reform has a significant influence on the performance of Dr. R. Soedjono Selong as indicated by ( $p$ value $=0,000$ or $<0.05$ ) and the strength of influence is moderate, amounting to 0.422 means that the better the bureaucratic reforms, the better the employee performance. The magnitude of the influence of the Bureaucratic Reform on performance is determined by leadership and work procedures which include courage, commitment, integrity, resposivity, professionalism, discipline, initiative, able to make the people around them achievement and motivation indicators. That is, leadership and work procedures become an important part in an effort to implement change.

2. Work culture variables have a significant influence on the performance of Dr. RSUD employees R. Soedjono Selong indicated by ( $p$ value 0.001 or $<0.05$ ) and the strength of influence is weak that is equal to 0.211 means that the better the work culture the more the employee performance increases. The magnitude of the influence of work culture is determined by the dimensions of behavior when working, work ethic, attitude towards time, and the method or tool used. To explain the right strategy to be used in improving the performance of RSUD Dr. R. Soedjono Selong, arranged a symbolic model that the writer formulated as an ARITMATIC model consisting of Ability, Responsibility, Innovation, Team Work, Motivation, Agility, Technology, Information and Culture.

\section{REFERENCES}

1. Albrow, M. (1989). Birokrasi. Yogyakarta: Tiara Wacana.

2. Apter, D. (1965). Comperative Politics. New York: The Free Press.

3. KepMenPAN Nomor 26/M.PAN/2/2004 Tentang Petunjuk Teknis Transparansi dan Akuntabilitas Dalam Penyelenggaraan Pelayanan Publik Menteri Pendayagunaan Aparatur Negara.

4. Mangkunegara, A.A.A.P. (2011). Manajemen Sumber Daya Manusia Perusahaan. Bandung: PT. Remaja Rosda Karya.

5. Mangkunegara, A.A.A.P. (2012). Evaluasi Kinerja SDM. Bandung: PT. Remaja Rosda Karya.

6. Mar'at. (2001). Sikap Manusia Perubahan Serta Pengukurannya. Jakarta: Ghalia Indonesia.

7. Moleong, L. J. (2000). Metode Penelitian Bidang Kualitatif. Bandung: Remaja Rosdakarya Offset. 
8. Ndraha. (1997). Budaya Organisasi. Jakarta: Rineka Cipta.

9. Ndraha. (2000). Diktat Kuliah Ilmu Pemerintahan. Program Pasca Sarjana UNPAD.

10. Ndraha. (2003). Kybernology (Ilmu Pemerintahan Baru Jilid 1).Jakarta: Rineka Cipta.

11. Ndraha. (2011). Kybernology (Ilmu Pemerintahan Baru Jilid II). Jakarta: Rineka Cipta.

12. Prawirosentono, S. (1999). Kebijakan Kinerja Karyawan. Yogyakarta: BPFE.

13. Sedarmayanti. (1996). Tata Kerja dan Produtivitas Kerja. Bandung: CV. Mandar Maju.

14. Setiyono, B. (2004). Birokrasi Dalam Perspektif Politik dan Administrasi. Semarang: Puskodak Undip.

15. Sugiyono. (2002). Metode Penelitian Administrasi. Bandung: CV. Alfabeta.

16. Suradinata, E. (2016). Analisis Kepemmpinan. Sumedang: Alqaprint Jatinangor. 